\title{
Holistic requirements analysis for specifying new systems for 3D media production and promotion
}

\author{
Christos Mouzakis, Dimitrios Ververidiss,", Luis Miguel Girao², Nicolas Patz ${ }^{3}$, Spiros Nikolopoulos, and Ioannis \\ Kompatsiaris $^{1}$ \\ 1 Centre for Research \& Technology Hellas, Information Technologies Institute, CERTH-ITI, Thermi, Greece \\ 2 Research Center for Science and Technology of the Arts, CIDAR, Porto, Portugal \\ 3 Deutsche Welle, Broadcast media, Berlin, Germany \\ * Correspondence: ververid@iti.gr;
}

\begin{abstract}
This paper presents a requirements specification analysis for driving the design of new systems that will allow 3D media creators to further promote and monetize from their work. The provided requirements analysis is based on the IEEE 830 standard for requirements specification. It allows us to elucidate system requirements through existing (AS-IS) and envisioned (TO-BE) scenarios affected by the latest trends on design methodologies and content promotion in social media. A total of 30 tools for content creation, promotion and monetization are reviewed. The target groups, i.e. creator groups, are divided in 10 types according to their role in 3D media production. Based on this division 10 candidate TO-BE scenarios have been identified and out of these 10 scenarios, we have selected 6 scenarios for validation by media creators. The validation was performed through a survey of 24 statements on a 5 Likert scale by 47 individuals from the domains of Media, Fine arts, Architecture, and Informatics. Useful evaluation results and comments have been collected that can be useful for future systems design.
\end{abstract}

Keywords: Requirements Engineering; Authoring Tools; 3D content; IEEE 830 standard; Social Media

\section{Introduction}

Cultural organizations are under extreme pressure as visitor admissions in cultural spaces have been diminished due to the coronavirus pandemy. Cultural heritage $(\mathrm{CH})$ institutions, galleries, and artists have to find alternative ways to attract audiences. One way to deal with the crisis is through the emerging 3D technologies. Digital innovation can help towards various goals such as education, dissemination, and monetization from the artistic creations which can potentially lead into a sustainable digital product.

As technology progresses, virtual experiences become part of societal life. This does not only mean that people spend more time in virtual experiences such as 3D games, AR apps, and VR immersive games, but also seek the reflectance of virtual experiences in each part of their lives, including traditional media. Art and $\mathrm{CH}$ in general need also to conform with this 'virtual reality' norm so as not to risk loosing part of their audience. Museums, galleries, and other stakeholders in $\mathrm{CH}$ are in need of tools that will allow their content to be consumed through virtual experiences such as games, VR, AR and blended versions of them, so as to attract their audience. Companies for mobile apps such Instagram, TikTok, and Facebook have realized this need and offer some limited tweaks such as live facial AR masks, aging filters, and graphic overlays.

This work is part of a research project called MediaVerse that has the purpose to investigate new media [1]. The traditional media landscape is in the middle of a monumental shift: boundaries between professional media houses, prosumers and small creators are blurring, the speed of communication and publishing is increasing, audiences 
are seeking more user-driven and accessible multimedia experiences. This is where MediaVerse comes in: MediaVerse aims to enable all sorts of content creators, from traditional publishers and freelance creators or artists to anyone who wants to share their ideas, to create and share their media, while keeping control of their intellectual property rights. In this paper, we have adopted the IEEE 830 Requirements Specification Standard $[2,3,4]$, in order to investigate more thoroughly the needs of relevant audiences and derive the conclusions necessary to lead future developments in the project.

The paper is structured as follows. In Section 2, we review existing tools related to content creation. In Section 3, we describe the methodology adopted for requirements analysis that it is based on finding candidate scenarios for evaluation by creators. In Section 4, we present the results of the survey conducted for evaluating these scenarios. In Section 5, a discussion about the results is provided. Finally, conclusions are derived in Section 6.

\section{Review of previous work}

This section provides an overview of the existing tools allowing to create 3D content. Several of these tools can be found in Table 1.

Table 1. Authoring tools for VR experiences in Arts and Culture.

\begin{tabular}{|c|c|c|c|c|c|c|}
\hline & Name & Target Group & Type & Medium & Scope & Features \\
\hline 1 & $\begin{array}{l}\text { 3D Vista Pro } \\
\text { (https://www.3dvista.c } \\
\text { om/) }\end{array}$ & $\begin{array}{l}\text { Amateur VR } \\
\text { experiences } \\
\text { designers }\end{array}$ & $\begin{array}{l}\text { Appli } \\
\text { cation }\end{array}$ & Desktop & $\begin{array}{l}\text { VR experience design. } \\
\text { Author experiences based } \\
\text { on } 360 \text { videos }\end{array}$ & $\begin{array}{l}\text { Allow to place tags onto video } \\
\text { objects while they are moving. }\end{array}$ \\
\hline 2 & $\begin{array}{l}\text { Adobe Illustrator/XD } \\
\text { (https://adobe.com/pro } \\
\text { ducts/illustrator.html) }\end{array}$ & $\begin{array}{l}\text { Graphic } \\
\text { designers }\end{array}$ & $\begin{array}{l}\text { Appli } \\
\text { cation }\end{array}$ & Desktop & $\begin{array}{l}\text { Authoring digital visual } \\
\text { arts designs based on 2D } \\
\text { and 3D geometries }\end{array}$ & $\begin{array}{l}\text { 3D and 2D editor; Dynamic } \\
\text { brushes; Painting; Export interface } \\
\text { designs. }\end{array}$ \\
\hline 3 & $\begin{array}{l}\text { Adobe Medium } \\
\text { (https://www.adobe.co } \\
\underline{\mathrm{m} / \text { products/medium.ht }} \\
\underline{\mathrm{ml}} \text { ) }\end{array}$ & $\begin{array}{l}\text { Graphics } \\
\text { designers }\end{array}$ & $\begin{array}{l}\text { Appli } \\
\text { cation }\end{array}$ & VR & $\begin{array}{l}\text { Create 3D geometries and } \\
\text { textures inside VR space }\end{array}$ & $\begin{array}{l}\text { Sculpting and other tools that } \\
\text { simulate real environments. } \\
\text { Maximum level of detail for } \\
\text { professional use. }\end{array}$ \\
\hline 4 & $\begin{array}{l}\text { Adobe Premiere } \\
\text { (https://www.adobe.co } \\
\underline{\mathrm{m} / \text { products/premiere.h }} \\
\underline{\mathrm{tml}} \text { ) }\end{array}$ & $\begin{array}{l}\text { Professional } \\
\text { video makers }\end{array}$ & $\begin{array}{l}\text { Appli } \\
\text { cation }\end{array}$ & Desktop & $\begin{array}{l}\text { Video and audio editor; } \\
\text { Author videos for } \\
\text { stereoscopic VR glasses. }\end{array}$ & $\begin{array}{l}\text { Allow to place tags onto video } \\
\text { objects; Media uploader; Allow } 3^{\text {rd }} \\
\text { party plugins for VR effects, e.g. } \\
\text { Torusmedialabs Canvas } 360 \text {. }\end{array}$ \\
\hline 5 & $\begin{array}{l}\text { Amazon Sumerian } \\
\text { (https://aws.amazon.co } \\
\underline{\mathrm{m} / \text { sumerian/) }}\end{array}$ & $\begin{array}{l}\text { Professional } \\
\text { VR designers }\end{array}$ & Web & Desktop & $\begin{array}{l}\text { Interface to author } \\
\text { general purpose VR } \\
\text { environments with } \\
\text { avatars }\end{array}$ & $\begin{array}{l}\text { 3D editor targeting programmers; } \\
\text { Amazon speech synthesis and } \\
\text { recognition addons. }\end{array}$ \\
\hline 6 & $\begin{array}{l}\text { Cospaces } \\
\text { (https://cospaces.io/ed } \\
\underline{\mathrm{u}})\end{array}$ & $\begin{array}{l}\text { Educators for } \\
\text { art and design } \\
\text { in schools }\end{array}$ & Web & Desktop & $\begin{array}{l}\text { Allow children to author } \\
\text { and program 3D cultural } \\
\text { experiences }\end{array}$ & $\begin{array}{l}\text { 3D editor; visual programming } \\
\text { interface; class management; VR } \\
\text { support. }\end{array}$ \\
\hline 7 & $\begin{array}{l}\text { Dataverse.xyz } \\
\text { https://dataverse.xyz/ }\end{array}$ & $\begin{array}{l}\text { Amateur VR } \\
\text { designers }\end{array}$ & Web & $\begin{array}{l}\text { Google } \\
\text { sheets }\end{array}$ & $\begin{array}{l}\text { Allow artists to present a } \\
\text { story in 3D space through } \\
\text { table sheets as input. }\end{array}$ & $\begin{array}{l}\text { Editor based on google sheets; } \\
\text { Multiple layouts of } 360 \text { VR scenes } \\
\text { based on } 5 \text { templates; Open source. }\end{array}$ \\
\hline 8 & $\begin{array}{l}\text { Desktop 3D design } \\
\text { tools (Blender, Maya, } \\
\text { Cinema 4D, 3DS Max })\end{array}$ & $\begin{array}{l}\text { Graphics } \\
\text { designers }\end{array}$ & $\begin{array}{l}\text { Appli } \\
\text { cation }\end{array}$ & Desktop & $\begin{array}{l}\text { Author digital visual arts } \\
\text { designs and sculptures } \\
\text { based on 3D geometries. }\end{array}$ & $\begin{array}{l}\text { 3D editor; Dynamic brushes; 3D } \\
\text { painting; Poly integration; } \\
\text { animation control. }\end{array}$ \\
\hline 9 & $\begin{array}{l}\text { Experizer } \\
\text { https://experizer.com/ }\end{array}$ & $\begin{array}{l}\text { Amateur VR } \\
\text { designers }\end{array}$ & Web & Desktop & $\begin{array}{l}\text { Allow the presentation of } \\
\text { information in 3D. }\end{array}$ & $\begin{array}{l}\text { 3D Editor; Several templates; } \\
\text { Quizzes support; Storyline support. }\end{array}$ \\
\hline & $\begin{array}{l}0 \text { Fader } \\
\text { https://getfader.com/ }\end{array}$ & $\begin{array}{l}\text { Amateur VR } \\
\text { designers }\end{array}$ & Web & Desktop & $\begin{array}{l}\text { Author stories and tours } \\
\text { through } 360 \text { images and } \\
\text { videos }\end{array}$ & $\begin{array}{l}\text { Tags placement; Media uploader; } \\
\text { Tags insertion; scenes } \\
\text { interconnection. }\end{array}$ \\
\hline & $\begin{array}{l}1 \text { Filmmaker Live } \\
\text { (https://filmmakerlive. } \\
\underline{\text { com) }}\end{array}$ & $\begin{array}{l}\text { Amateur VR } \\
\text { Designers }\end{array}$ & $\begin{array}{l}\text { Appli } \\
\text { cation }\end{array}$ & VR & $\begin{array}{l}\text { Author a story with } \\
\text { audiovisual content. }\end{array}$ & $\begin{array}{l}\text { Video editor; Camera Editor; Media } \\
\text { uploader; Multiplaying. }\end{array}$ \\
\hline
\end{tabular}




\begin{tabular}{|c|c|c|c|c|c|}
\hline $\begin{array}{l}12 \text { Google Blocks } \\
\text { https://vr.google.com/b } \\
\underline{\text { locks/ }}\end{array}$ & $\begin{array}{l}\text { Amateur VR } \\
\text { Designers }\end{array}$ & $\begin{array}{l}\text { Appli } \\
\text { cation }\end{array}$ & VR & $\begin{array}{l}\text { Author digital designs } \\
\text { and sculptures based on } \\
\text { 3D geometries. }\end{array}$ & $\begin{array}{l}\text { 3D editor; VR support; Dynamic } \\
\text { brushes; 3D painting; Google Poly } \\
\text { repository integration. }\end{array}$ \\
\hline $\begin{array}{l}13 \text { Google Tilt Brush } \\
\text { https://www.tiltbrush. } \\
\text { com/ }\end{array}$ & $\begin{array}{l}\text { Professional } \\
\text { VR designers }\end{array}$ & $\begin{array}{l}\text { Appli } \\
\text { cation }\end{array}$ & VR & $\begin{array}{l}\text { Author digital designs } \\
\text { and sculptures based on } \\
\text { 3D geometries. }\end{array}$ & $\begin{array}{l}\text { Dynamic brushes; 3D painting; } \\
\text { Intuitive interface; Google Poly } \\
\text { repository integration. }\end{array}$ \\
\hline $\begin{array}{l}14 \text { Google Tour Creator } \\
\text { https://arvr.google.com } \\
\text { ttourcreator/ }\end{array}$ & $\begin{array}{l}\text { Amateur VR } \\
\text { Experiences } \\
\text { designers }\end{array}$ & $\begin{array}{l}\text { Appli } \\
\text { cation }\end{array}$ & Desktop & $\begin{array}{l}\text { Basic VR experiences } \\
\text { using } 360 \text { media }\end{array}$ & $\begin{array}{l}\text { Allow to place tags onto video } \\
\text { objects while they are moving. }\end{array}$ \\
\hline $\begin{array}{l}15 \text { Isadora } \\
\text { (https://troikatronix.co } \\
\underline{\mathrm{m} /)}\end{array}$ & $\begin{array}{l}\text { Novice } \\
\text { programmers }\end{array}$ & Code & $\begin{array}{l}\text { Code } \\
\text { editor }\end{array}$ & $\begin{array}{l}\text { Create audiovisual effects } \\
\text { that can be used inside } \\
\text { immersive experiences. }\end{array}$ & $\begin{array}{l}\text { Show control; Lighting editor; } \\
\text { Multimedia editor; visual } \\
\text { programming interface. }\end{array}$ \\
\hline $\begin{array}{l}16 \text { MaxMSP } \\
\text { (https://cycling74.com/ }\end{array}$ & $\begin{array}{l}\text { Multimedia } \\
\text { Creators }\end{array}$ & Code & $\begin{array}{l}\text { Code } \\
\text { editor }\end{array}$ & $\begin{array}{l}\text { Author audio content for } \\
\text { VR applications. }\end{array}$ & $\begin{array}{l}\text { Visual programming interface; } \\
\text { multimedia editor; Script editor; } \\
\text { Open source }\end{array}$ \\
\hline $\begin{array}{l}17 \text { Mozilla Hubs } \\
\underline{\text { https://hubs.mozilla.co }} \\
\underline{\mathrm{m} /}\end{array}$ & $\begin{array}{l}\text { Amateur } \\
\text { VR Designers }\end{array}$ & Web & Desktop & $\begin{array}{l}\text { Author 3D spaces for } \\
\text { social interaction }\end{array}$ & $\begin{array}{l}\text { Multiplaying; Google Poly and } \\
\text { Sketchfab asset fetching; Open } \\
\text { source. }\end{array}$ \\
\hline
\end{tabular}

\begin{tabular}{|c|c|c|c|c|c|}
\hline $\begin{array}{l}18 \text { Nuke } \\
\text { https://www.foundry.c } \\
\text { om/products/nuke }\end{array}$ & $\begin{array}{l}\text { Professional } \\
\text { VR Designers }\end{array}$ & $\begin{array}{l}\text { Appli } \\
\text { cation }\end{array}$ & Desktop & $\begin{array}{l}\text { Author digital visual arts } \\
\text { designs based on } 360 \\
\text { media }\end{array}$ & $\begin{array}{l}\text { Scripts editor; } 2 \mathrm{D} \text { and } 3 \mathrm{D} \\
\text { compositing and visual effects; } \\
\text { visual programming interface. }\end{array}$ \\
\hline $\begin{array}{l}19 \text { OpenFrameworks } \\
\text { (https://openframewor } \\
\text { ks.cc/) }\end{array}$ & $\begin{array}{l}\text { Multimedia } \\
\text { programmers }\end{array}$ & Code & $\begin{array}{l}\text { Code } \\
\text { editor }\end{array}$ & $\begin{array}{l}\text { Author visual arts } \\
\text { experiences that can be } \\
\text { used inside VR. }\end{array}$ & $\begin{array}{l}\text { Script editor; camera editor; Open } \\
\text { source. }\end{array}$ \\
\hline $\begin{array}{l}20 \text { PlayCanvas } \\
\text { https://playcanvas.com }\end{array}$ & $\begin{array}{l}\text { Professional } \\
\text { VR Designers }\end{array}$ & Web & Desktop & $\begin{array}{l}\text { Author a VR game } \\
\text { without programming } \\
\text { skills. }\end{array}$ & $\begin{array}{l}\text { Asset uploader; animation control; } \\
\text { scripts editor; multiplaying. }\end{array}$ \\
\hline $\begin{array}{l}21 \text { Processing.org } \\
\text { https://processing.org/ }\end{array}$ & $\begin{array}{l}\text { Novice } \\
\text { Programmers }\end{array}$ & Code & $\begin{array}{l}\text { Code } \\
\text { Editor }\end{array}$ & $\begin{array}{l}\text { Create artistic content for } \\
\text { VR environments. }\end{array}$ & $\begin{array}{l}\text { Script editor; Movie editor; Open } \\
\text { source; Visual Editor. }\end{array}$ \\
\hline $\begin{array}{l}22 \text { Runtime Graphics } \\
\text { Engines (Unity, } \\
\text { Unreal, Unreal) }\end{array}$ & $\begin{array}{l}\text { Storyboardartis } \\
\text { ts and VR } \\
\text { professionals }\end{array}$ & $\begin{array}{l}\text { Appli } \\
\text { cation }\end{array}$ & Desktop & $\begin{array}{l}\text { Author general purpose } \\
\text { VR environments with } \\
\text { avatars for storytelling }\end{array}$ & $\begin{array}{l}\text { 3D editor; asset uploader; } \\
\text { animation control; scripts editor; } \\
\text { visual programming interface; }\end{array}$ \\
\hline $\begin{array}{l}23 \text { Sketchbox } \\
\text { (https://www.sketchbo } \\
\underline{\text { x3d.com/) }}\end{array}$ & $\begin{array}{l}\text { Amateur VR } \\
\text { experiences } \\
\text { designers }\end{array}$ & $\begin{array}{l}\text { Appli } \\
\text { cation }\end{array}$ & Desktop & $\begin{array}{l}\text { Educational tool for VR } \\
\text { training. }\end{array}$ & $\begin{array}{l}\text { Multiplaying; VR support; Asset } \\
\text { uploader; 3D editor. }\end{array}$ \\
\hline $\begin{array}{l}24 \text { SynthEyes } \\
\text { (https://www.ssontech. } \\
\underline{\underline{\mathrm{com} /})}\end{array}$ & $\begin{array}{l}\text { Professional } \\
\text { VR Designers }\end{array}$ & $\begin{array}{l}\text { Appli } \\
\text { cation }\end{array}$ & Desktop & $\begin{array}{l}\text { 3D camera tracking and } \\
\text { realistic exposition of } \\
\text { objects in VR based on } \\
360 \text { media. }\end{array}$ & $\begin{array}{l}\text { 3D camera tracking; camera editor; } \\
\text { Image preprocessor; } 360 \mathrm{VR} \\
\text { stabilization. }\end{array}$ \\
\hline $\begin{array}{l}25 \text { Thinglink } \\
\text { https://www.thinglink. } \\
\text { com/ }\end{array}$ & $\begin{array}{l}\text { Amateur VR } \\
\text { experience } \\
\text { designers }\end{array}$ & Web & Desktop & $\begin{array}{l}\text { Author basic experiences } \\
\text { based on } 360 \text { videos. }\end{array}$ & $\begin{array}{l}\text { Allow to place tags onto video } \\
\text { objects while they are moving. }\end{array}$ \\
\hline $\begin{array}{l}26 \text { Three.js } \\
\text { (https://threejs.org/) }\end{array}$ & $\begin{array}{l}\text { Professional } \\
\text { VR designers }\end{array}$ & Code & $\begin{array}{l}\text { Code } \\
\text { editor }\end{array}$ & $\begin{array}{l}\text { Authoring advanced 3D } \\
\text { visualizations accessible } \\
\text { through a web browser. }\end{array}$ & $\begin{array}{l}\text { Allow to visualize } 3 \mathrm{D} \text { models and } \\
360 \text { video, VR support, wide } \\
\text { community support. }\end{array}$ \\
\hline $\begin{array}{l}27 \text { VFX software } \\
\text { (Adobe After Effects, } \\
\text { MOCHA, Canvas 360) }\end{array}$ & $\begin{array}{l}\text { Professional } \\
\text { Experiences } \\
\text { designers }\end{array}$ & $\begin{array}{l}\text { Appli } \\
\text { cation }\end{array}$ & Desktop & $\begin{array}{l}\text { Author digital visual arts } \\
\text { designs based on } 360 \\
\text { media. }\end{array}$ & $\begin{array}{l}\text { Apply a posteriori video effects on } \\
\text { video. Used in creative industries } \\
\text { for various movies effects. }\end{array}$ \\
\hline $\begin{array}{l}28 \text { VVVV } \\
\text { (https://vvvV.org/) }\end{array}$ & $\begin{array}{l}\text { Novice } \\
\text { programmers }\end{array}$ & Code & $\begin{array}{l}\text { Code } \\
\text { editor }\end{array}$ & $\begin{array}{l}\text { Author interactive visual } \\
\text { creations and creative art } \\
\text { that can be used in VR. }\end{array}$ & $\begin{array}{l}\text { Script editor; Visual programming } \\
\text { interface; Animation control; Open } \\
\text { source. }\end{array}$ \\
\hline $\begin{array}{l}29 \text { WondaVR } \\
\text { https://www.wondavr. } \\
\text { com/ }\end{array}$ & $\begin{array}{l}\text { Professional } \\
\text { experiences } \\
\text { designers }\end{array}$ & $\begin{array}{l}\text { Appli } \\
\text { cation }\end{array}$ & Desktop & $\begin{array}{l}\text { Author social VR } \\
\text { environments for } \\
\text { storytelling. }\end{array}$ & $\begin{array}{l}\text { 3D editor; asset uploader; } \\
\text { animation control; scripts editor; } \\
\text { multiplaying. }\end{array}$ \\
\hline
\end{tabular}




\begin{tabular}{|c|c|c|c|c|c|}
\hline $\begin{array}{l}0 \text { Youtube VR } \\
\text { https://vr.youtube.com }\end{array}$ & $\begin{array}{l}\text { Amateur VR } \\
\text { experience } \\
\text { designers }\end{array}$ & Web & Desktop & $\begin{array}{l}\text { Author basic virtual tour } \\
\text { experiences based on } 360 \\
\text { or } 180 \text { media. }\end{array}$ & $\begin{array}{l}\text { Media uploader; Various VR } \\
\text { headsets support. }\end{array}$ \\
\hline
\end{tabular}

These applications can be categorized according to their target group:

1. Graphics designing tools: Tools that allow to create 3D models with color, texture, and animation, e.g. Google Tilt and Blocks, Adobe Medium, Blender, Maya, 3DS MAX, and Cinema4D.

2. Professional VR Experience design tools: Tools that require extensive knowledge and skills in editing or programming, e.g. tools like Unreal, Unity, 3D Vista pro, Amazon Sumerian, PlayCanvas, and WondaVR.

3. Amateur VR Experience design tools: Web based tools that are easily accessible for anyone, e.g. Google Tour Creator, Youtube VR, Dataverse.xyz, Experizer, Fader, Mozilla Hubs, and Thinklink.

4. Education on tools for VR: Tools that allow children to easily learn about synthesizing VR experiences, e.g. Cospaces.

5. Storyboard VR and VFX design tools: Graphics Engines such as Unity or Unreal that allow to make a VR movie, or tools that allow to post-edit a movie such as Adobe After Effects, Nuke, SynthEyes and MOCHA.

6. Open source coding libraries: Free libraries such as Isadora, MaxMSP, OpenFrameworks, Three.js, and VVVV that allow more freedom into synthesizing impressive visualizations.

These categories are explained in greater detail in the following.

Graphics design tools: Google Tilt Brush and Adobe Medium are useful tools for artists and designers to create visual arts in a virtual world and author virtual tours and galleries. Google Tilt Brush supports features like dynamic brushes, and it has intuitive interfaces mostly suitable for experts on artistic design. It is compatible for Vive, Oculus, Oculus Quest, Windows Mixed Reality, Valve Index and Playstation VR headsets. It requires the downloading of the software from Steam, Humble Store, Vive, Oculus or PlayStation Store. Recently, Google Blocks has been introduced which is similar to Tilt but much more simplified targeting for novice designers. Adobe Medium is a similar application available only for Oculus Rift and Oculus Quest headsets. It supports features like 3D editing and multi-playing. Other design tools available in the market are the "traditional" ones, i.e. those based on a desktop screen interface such as Blender, Maya, 3DS Max, and Cinema4D.

Professional VR experiences design tools: Many professional artists rely on programming interfaces and tools to generate content. In this category, Unreal, Unity and Godot Graphics Engines can be found which are often used to generate VR experiences. Amazon Sumerian is another tool which is based on web technologies for VR applications. It is compatible across VR headsets such HTC Vive, Oculus Go, Google Daydream and Hololens. It can be used to create VR tours like virtual museums and other subjects of cultural interest, e.g. a 360 video presentation which provides an immersive real-world experience to help travelers select their destination, accommodation or adventure. It has a 3D editor, Amazon Web Services speech synthesis and recognition, ready to use templates and assets. PlayCanvas is a 3D editor for VR applications targeting for novice programmers. The application has a cloud-hosted creation platform that allows multiple users to interact within the project. It supports features like asset uploader, animation control, scripts editor, multi-playing etc. Wonda VR is an application for novice programmers based both on 3D geometries and 360 media to generate VR experiences. The scope of the application is to author social VR environments for immersive storytelling and interactive branching narratives. It supports features like 3D editor, asset uploader, animation control, scripts editor and multi-playing. 
Amateur VR experiences design tools: Artists, Journalists and other amateur content creators often resort to the solutions of this category where VR experiences are easily authored through 360 media. Several tools can be found in this category such as:

1) Google Tour Creator is an authoring tool for anyone to create a VR experience through desktop, Android or iOS devices. The user imports photos and does basic editing like adding audio or points of interest. It can be used for virtual art galleries and other subjects of cultural interest with low need of interactions;

2) Thinglink is a similar application. Thinglink is an exposition tool for virtual galleries and other subjects of cultural interest. Supports interactive tags, 360 media editor and is compatible across VR headsets such as Oculus GO, Google Daydream, Hololens etc.

3) Experizer is another such type of authoring tool accessible through a web browser. The scope of the application is to author immersive interactive virtual tours and presentations. It also supports quizzes, a storyline, and can analyze the activity of users and track score. It can create immersive 360 experiences for a quest.

4) Fader is another similar authoring tool. It also offers the possibility to embed the projects directly to developers website and supports live editing on them even after the exposition.

5) Mozilla Hubs is an open source VR authoring tool for web browser users. The scope of the application is to author 3D spaces for social interaction by making virtual rooms. Hubs supports features like multi-playing, importing 3D models, and allowing to position 3D emoticons in the environment. It has a 3D editor named as Spoke that can be used to create new levels. A novel feature of Spoke is that performs automatic estimation of the navigation mesh on the whole scene in order to make a compact form of colliders and preserve resources, which is very useful for web applications. It can also change lights positions, and provide the ability to manage animations. It can be used for authoring virtual galleries, museums and other types of venues. It can support more than one hundred concurrent users through Amazon hosting services.

6) YouTube VR: Compatible to all VR headsets, Youtube VR, allows the users to watch any video on YouTube and provide an immersive VR experience whether it is on 360 degree video or a standard video shown in a cinema-style mode. For editors, supports both 360 and 180 VR format.

7) 3D Vista Pro allows users to place tags onto video objects while they are moving. It also allows the user to combine multiple 360-degree photos into one to create a timelapse effect. Other features include the sharing ability to social media, and providing the guest immediate access to maps, floor plans, and panoramic images of the tour.

8) Dataverse.xyz is an open source VR authoring tool for 360 media, which exploits google sheets as an editing environment. It allows artists or journalists to present a story in VR through 8 visualization templates (Geo Viz, Map, isotypes, 360 photo, 360 video, PhotoGrid, TimeLine and TreeMap).

Free coding tools for Art: Many artists prefer to do designs by coding in free programming tools. These tools have particular interest as they can be used to make audiovisual content for VR environments. Prominent examples are Isadora, MaxMSP, OpenFrameworks, Three.js, Processing and VVVV.

1) Isadora is an authoring tool based on programming that allows to create immersive experiences and visual arts designs. Supports a variety of uses during live performances, e.g. from simple video playback up to complex interactive scene control. It has a visual programming interface to help artists create immersive interactions and editing interfaces.

2) MaxMSP is a visual programming tool for multimedia developers to author interactive software. As with most of the tools mentioned above, it has a visual programming interface. Other features are a javascript editor and an audio editor to create interactive channels. 
3) OpenFrameworks is an open source framework for professional programmers to author visual arts experiences. It requires knowledge of $\mathrm{C}++$. It provides a simplified interface for hardware control, media handling and network communication.

4) VVVV is a coding tool for novice programmers to author interactive visual installations and creative art. It requires basic knowledge of C\#. It has a visual programming interface, a script editor, animation control, and a video editor. The VVVV.OpenVR pack contains nodes to get pose data and render a 3D scene into any VR headset supported by SteamVR. VVVV is free only for non-commercial use.

5) Processing is an open source graphical tool for novice programmers in order to create digital visual arts. It started as an introduction tool for the basics of computer programming in a visual context, to evolve into a professional programming environment. Supports features like editing in JavaScript and a movie editor.

6) Three.js is a popular open source framework that builds on top of WebGL to offer 3D visualization, animation, and sound. It requires basic knowledge of HTML and Javascript. It has been evolved through its related A-frame framework into a tool for creating VR environments with few lines of code.

Education on VR design: This category contains useful tools for educational purposes that help students or employees to easily learn subjects of interest.

1) CoSpaces is an authoring tool for children that allows them to generate artistic creations with primitive 3D objects, avatars, and 360 media. It is a simplified version of more complex tools such as Blender or Unity. CoSpaces has a 3D editor, a visual programming interface, a class management interfaces, a physics engine (e.g. for object collisions), and VR capability. It is compatible across VR headsets such Mobile VR, Oculus Go, Google Daydream, Samsung VR and Class VR. With CoSpaces kids can design a virtual exhibition, build an immersive virtual tour based on 360 media, program their own game, and create an interactive story on virtual world.

2) SketchBox is an application for learning in VR. Collaborative with $3 \mathrm{D}$ design applications such as Tinkercad, it is an easy to use tool for simulation. It supports features like a 3D editor, an asset uploader and multi-playing. It is also a tool to sketch ideas and explain them to others.

Storyboard and VFX design tools: This category contains tools that allows experts in design to generate storyboards, virtual productions, real-time XR productions, and apply special effects on movies. Graphics Engines such as Unity, Unreal, Godot and Blender can be found in this category. Other editing tools are movie editing tools such as Adobe After Effects and TorusMediaLabs 360 Canvas for Adobe Premiere that allow to easily change background font or foreground characters with 3D graphics.

\section{Requirements collection procedure}

A requirement is defined by IEEE [2,3,4] as: 1) a condition or capability needed by a user or a system to solve a problem or achieve a goal; 2 ) a condition or capability, which has to be provided by a system to fulfil a contract, a standard, a specification or any other formal documentation; and 3) a documented representation of a condition or capability. In our work, particular gravity has the third definition as we want to find a well justified and documented representation of a capability for future developments during a Requirements Engineering (RE) process. Overall, the RE process is depicted in Figure 1 and it consists of the following steps: 1) Preparation; 2) Elicitation; 3) Analysis; 4) Specification; and 5) Validation.

The Preparation Phase consists of three steps. The first is related to the scenarios modelling. In this step a "Template for collection of scenarios" is defined. The aim is to distribute this form among artists and journalists so they can perform their contributions 
to the art industry scenarios identification. Based on this input information, modelling can be achieved. This step intends to provide the foundations and guidelines for the representation of various types of artists, so that the current process may be analysed and improved. Modelling or representing the current (AS-IS) situation is the basis for identifying shortcomings and potential improvements and forms the basis for the design of adequate models (TO-BE). The results of the template, namely the AS-IS and TO-BE models for art are summarized in 10 cases in Table 2.

Both the AS-IS model which represents the current situation as it is, and the TO-BE model, resulting from incorporating the desired improvements, are equally important. Catalysts are the new trends that appear in society and particular in electronically generated visual arts. These will allow the proposed system to find a track on the market of creative industries.

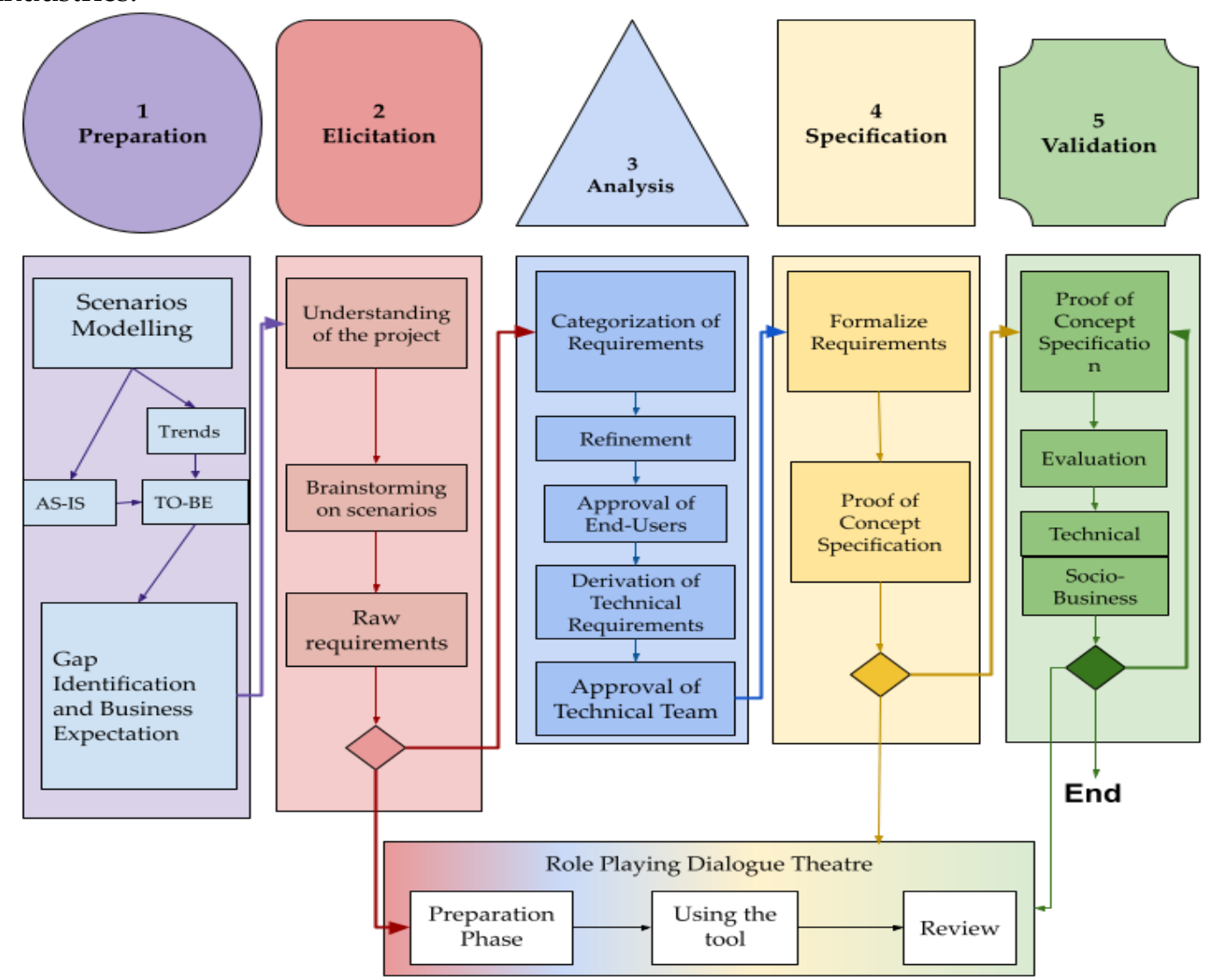

Figure 1: Requirement Engineering phases.

Table 2: Target user group activities and requirements engineering elicitation phase.

\begin{tabular}{|c|c|c|c|c|c|}
\hline$\#$ & Artist & Activity & $\begin{array}{l}\text { Current Tools } \\
\text { (AS-IS scenarios) }\end{array}$ & $\begin{array}{l}\text { Trends } \\
\text { (Opportunities) }\end{array}$ & Brainstorming TO-BE scenarios \\
\hline 1 & $\begin{array}{l}\text { Web UX } \\
\text { artist }\end{array}$ & $\begin{array}{l}\text { Make front- } \\
\text { end web } \\
\text { visualizations }\end{array}$ & $\begin{array}{l}\text { Adobe Illustrator } \\
\text { and XD, Figma, } \\
\text { WordPress, } \\
\text { Three.js }\end{array}$ & $\begin{array}{l}\text { Neomorphism, 3D, } \\
\text { Glassmorphism, VR, AR }\end{array}$ & $\begin{array}{l}\text { A flexible 3D viewer component for } \\
\text { web pages does not exist }\end{array}$ \\
\hline 2 & $\begin{array}{l}\text { Multimedia } \\
\text { - Graphics } \\
\text { Designer }\end{array}$ & $\begin{array}{l}\text { Developing } \\
\text { audiovisual } \\
\text { storyboards }\end{array}$ & $\begin{array}{l}\text { Adobe After } \\
\text { Effects, Premier, } \\
\text { Photoshop }\end{array}$ & $\begin{array}{l}\text { Content and ads creators } \\
\text { in Youtube, Facebook, } \\
\text { Instagram }\end{array}$ & $\begin{array}{l}\text { Adobe suite is too expensive. A } \\
\text { commercial gap exists. }\end{array}$ \\
\hline 3 & VFX artist & $\begin{array}{l}\text { Create post- } \\
\text { production } \\
\text { effects }\end{array}$ & $\begin{array}{l}\text { Adobe After } \\
\text { Effects \& } \\
\text { Premier, Nuke, } \\
\text { Maya, MOCHA }\end{array}$ & $\begin{array}{l}\text { Social media content } \\
\text { creators in Tik-tok, } \\
\text { Youtube etc. Animators } \\
\text { code in Python AI tools. }\end{array}$ & $\begin{array}{l}\text { Setting rotoscopy object borders } \\
\text { takes too much time; No high } \\
\text { resolution is needed for social media. }\end{array}$ \\
\hline
\end{tabular}




\begin{tabular}{|c|c|c|c|c|c|}
\hline 4 & $\begin{array}{l}\text { 3D models } \\
\text { artists }\end{array}$ & $\begin{array}{l}\text { Design the } \\
\text { geometry of } \\
\text { 3D models }\end{array}$ & $\begin{array}{l}\text { Maya, Blender, } \\
\text { Cinema4D, Pix4D, } \\
\text { Agisoft }\end{array}$ & $\begin{array}{l}\text { Design within VR with } \\
\text { Google Tilt or Adobe } \\
\text { Medium; Capture with } \\
\text { Photogrammetry. }\end{array}$ & $\begin{array}{l}\text { Tilt and Medium are difficult to } \\
\text { operate; Google Blocks is easier but it } \\
\text { a has fewer capabilities. Photogram- } \\
\text { metry retrieves too noisy meshes. }\end{array}$ \\
\hline 5 & $\begin{array}{l}\text { Digital 3D } \\
\text { Animation } \\
\text { artist }\end{array}$ & $\begin{array}{l}\text { Animate a 3D } \\
\text { model }\end{array}$ & $\begin{array}{l}\text { Blender, Maya, } \\
\text { Cinema4D, } \\
\text { Zbrush, 3DS Max, } \\
\text { iClone, Daz3D, } \\
\text { Rokoko }\end{array}$ & $\begin{array}{l}\text { Prefixed, surreal and } \\
\text { retro 3D filters in tiktok } \\
\text { applied with localization } \\
\text { on top of video. } \\
\text { Bodysuits. }\end{array}$ & $\begin{array}{l}\text { Pre-fixed animations as in mobile } \\
\text { apps become boring. Keyframing is a } \\
\text { tedious procedure. Rotoscoping } \\
\text { needs an automation to find the } \\
\text { borders of objects automatically. }\end{array}$ \\
\hline 6 & $\begin{array}{l}\text { 3D Texture } \\
\text { artist }\end{array}$ & $\begin{array}{l}\text { Paint 3D } \\
\text { models } \\
\text { material } \\
\text { layers. }\end{array}$ & $\begin{array}{l}\text { GIMP, Photoshop, } \\
\text { Blender, Maya, } \\
\text { Mari, Substance } \\
\text { Painter }\end{array}$ & $\begin{array}{l}\text { Represent materials with } \\
\text { high realism exploiting } \\
\text { the latest GPU } \\
\text { technologies. Problems } \\
\text { in Photogrammetry. }\end{array}$ & $\begin{array}{l}\text { Materials are not compatible across } \\
\text { graphics engines, e.g. Maya with } \\
\text { Unity. Photogrammetry assesses all } \\
\text { layers in one material map which } \\
\text { should be decomposed into layers. }\end{array}$ \\
\hline 7 & $\begin{array}{l}\text { Scientific } \\
\text { illustrations } \\
\text { artist }\end{array}$ & $\begin{array}{l}\text { Draw 3D } \\
\text { models of } \\
\text { scientific } \\
\text { elements }\end{array}$ & $\begin{array}{l}\text { Adobe Illustrator, } \\
\text { Blender, Maya, } \\
\text { Gimp, Photoshop }\end{array}$ & $\begin{array}{l}\text { Many artists have } \\
\text { WordPress personal } \\
\text { blogs for their work } \\
\text { promotion. COVID19 } \\
\text { has attracted the } \\
\text { attention of the public. }\end{array}$ & $\begin{array}{l}\text { WordPress does not support 3D } \\
\text { models. The COVID biological } \\
\text { processes are too complex for the } \\
\text { audience to learn and remember. 3D } \\
\text { models need proper sound coverage } \\
\text { to be presented in an immersive way. }\end{array}$ \\
\hline 8 & $\begin{array}{l}\text { Story-telling } \\
\text { artist }\end{array}$ & $\begin{array}{l}\text { Make movies } \\
\text { or cutscenes }\end{array}$ & $\begin{array}{l}\text { Unity, Unreal, } \\
\text { Godot, Blender } \\
\text { Graphics Engines }\end{array}$ & $\begin{array}{l}\text { Real-time productions: } \\
\text { Visualize the imaginary } \\
\text { in real-time. }\end{array}$ & $\begin{array}{l}\text { COVID has been an impediment to } \\
\text { real productions. There is a need to } \\
\text { allow actors to collaborate remotely. }\end{array}$ \\
\hline 9 & $\begin{array}{l}\text { School } \\
\text { STEAM } \\
\text { teacher }\end{array}$ & $\begin{array}{l}\text { Educate } \\
\text { children } \\
\text { about 3D } \\
\text { technologies }\end{array}$ & $\begin{array}{l}\text { Cospaces, } \\
\text { Tinkercad }\end{array}$ & $\begin{array}{l}\text { Visual programming is } \\
\text { gaining ground for } \\
\text { setting the behaviour of } \\
\text { objects. }\end{array}$ & $\begin{array}{l}\text { WebGPU standard will change the } \\
\text { landscape of web browsers graphics } \\
\text { with more realistic graphics. } \\
\text { Cospaces and Tinkercad have low } \\
\text { resolution. }\end{array}$ \\
\hline 10 & $\begin{array}{l}\text { Researcher } \\
\text { Artist }\end{array}$ & $\begin{array}{l}\text { Generate and } \\
\text { visualize 3D } \\
\text { content }\end{array}$ & $\begin{array}{l}\text { Three.js, VVVV, } \\
\text { MaxMSP, Isadora, } \\
\text { Processing, } \\
\text { OpenFrameworks }\end{array}$ & $\begin{array}{l}\text { Artists became } \\
\text { programmers and } \\
\text { explore code and node } \\
\text { based editing }\end{array}$ & $\begin{array}{l}\text { Connecting music to textures to } 3 \mathrm{D} \text { is } \\
\text { something it is missing from the } \\
\text { market, e.g. connect MaxMSP to } \\
\text { Three.js }\end{array}$ \\
\hline
\end{tabular}

Elicitation: The requirements elicitation phase represents all the actions performed to acquire raw requirements related to what is intended to develop in the project. The purpose of our project is to construct a platform that can help artists such as those in the first column of Table 2 to do their job more efficiently, quicker, with lower cost, or publish and disseminate it better. In principle, the requirements are defined according to the traditional internal expectations such as an increase in profits; production cost savings; streamlining of processes; reduction of creation times; shortening of processing times; receive up-to-date information; achieve better communication between production units; or minimizing of idle times. On the other hand, some of the common external customer and/or market-oriented socio-business expectations are higher process quality and resulting product quality; closer proximity to customers and better customer commitment; and faster communication with market partners [4]. These socio-business indicators are clearly defined in order to be later used for progress measurement.

A formalization of the requirements according to the IEEE 830 standard characteristics is presented in Table 3 [2]. These characteristics are Unambiguity, Completeness, Consistency, Verifiability, Relevancy and Feasibility. The most important is Unambiquity which is a perceivable definition of the requirement. Many Requirements Specification Languages (RSLs) exist from the early 80s. However, we prefer to define the requirement in Attempto Control English (ACE) which is a natural language [5]. Although not tested with a ACE parser, the premature descriptions allow to confine the definition of the 
component and to be a seed for future official tests. With respect to Completeness, a short concise description of the requirement is provided. As regards Consistency, it regards conflicts in the implementation of the proposed requirement. For example, some requirements have inconsistencies from which the most important is security. Although WebGL standard is designed according to security standards, a poor implementation might be open to penetration attacks. As regards the use of web camera for applications targeted to children, they will have to grant access to a web page or a native program to access their camera. This may be an impedance to the application adoption. As regards Verifiability, several requirements do not have a quantitative result that can be measured directly, e.g. how good are visual effects on a video or how well are the borders of objects are defined on a video stream. In such cases user evaluation quality tests are required. Relevancy is correlated to the scope, the budget, and the contract terms of the project, namely to develop a 3D media related system for artists. As regards feasibility, budget and current state of the art was taken into consideration.

Table 3: Understanding the requirements.

\begin{tabular}{|c|c|c|c|c|c|c|c|}
\hline & Requirement & Unambiguity & Completeness & $\begin{array}{l}\text { Consistenc } \\
\mathrm{y}\end{array}$ & $\begin{array}{l}\text { Verifiabil } \\
\text { ity }\end{array}$ & $\begin{array}{l}\text { Relev } \\
\text { ant? }\end{array}$ & $\begin{array}{l}\text { Feasibi } \\
\text { lity }\end{array}$ \\
\hline 1 & $\begin{array}{l}\text { Enhance Web page } \\
\text { user experience with } \\
\text { 3D models }\end{array}$ & $\begin{array}{l}\text { A web widget } \\
\text { to view } 3 \mathrm{D} \\
\text { models in a } \\
\text { web browser }\end{array}$ & $\begin{array}{l}\text { Major WebCMSes support; 3D commerce } \\
\text { standard support; animation and sound } \\
\text { support; CSS positioning support; no iframes } \\
\text { and rectangular boxes; }\end{array}$ & - & Yes & Yes & Yes \\
\hline 2 & $\begin{array}{l}\text { Apply visual effects } \\
\text { on short term videos }\end{array}$ & $\begin{array}{l}\text { Web 3D Effects } \\
\text { composer }\end{array}$ & $\begin{array}{l}\text { Seamless 3D effects on video; web interface; no } \\
\text { coding interfaces; access through major social } \\
\text { media. }\end{array}$ & - & $\begin{array}{l}\text { Subjective } \\
\text { verificatio } \\
\mathrm{n}\end{array}$ & Yes & Yes \\
\hline 3 & $\begin{array}{l}\text { Separate persons in } \\
\text { video streams }\end{array}$ & $\begin{array}{l}\text { Auto-rotoscope } \\
\text { separation } \\
\text { algorithm }\end{array}$ & $\begin{array}{l}\text { No human segmentation process; Web } \\
\text { interface; no more than } 5 \text { clicks to finish the } \\
\text { process. }\end{array}$ & - & $\begin{array}{l}\text { Subjective } \\
\text { verificatio } \\
\mathrm{n}\end{array}$ & No & Maybe \\
\hline 4 & $\begin{array}{l}\text { Photogrammetry } \\
\text { geometries } \\
\text { correction }\end{array}$ & $\begin{array}{l}\text { Fix } \\
\text { Photogrammetr } \\
\text { y geometries }\end{array}$ & $\begin{array}{l}\text { Auto-filling gaps in 3D models; Auto-remove } \\
\text { vertices when they are too dense; Symmetrize } \\
\text { objects. }\end{array}$ & $\begin{array}{l}\text { No } \\
\text { informatio } \\
n \text { for gaps }\end{array}$ & $\begin{array}{l}\text { Subjective } \\
\text { verificatio } \\
\mathrm{n}\end{array}$ & No & Maybe \\
\hline 5 & $\begin{array}{l}\text { Rotoscope video for } \\
\text { applying movement } \\
\text { to 3D animation }\end{array}$ & $\begin{array}{l}\text { Photo to 3D } \\
\text { animation } \\
\text { algorithm }\end{array}$ & $\begin{array}{l}\text { Estimate human skeleton automatically from } \\
\text { RGB camera [6]; Apply movement to 3D } \\
\text { models rigs. Web interface accessible to non- } \\
\text { programmers. }\end{array}$ & - & Yes & No & Yes \\
\hline 6 & $\begin{array}{l}\text { Separate } \\
\text { Photogrammetry } \\
\text { generated texture } \\
\text { layer to n-layers }\end{array}$ & $\begin{array}{l}\text { Materials } \\
\text { Demux } \\
\text { algorithm }\end{array}$ & $\begin{array}{l}\text { Provide one image, receive many images of the } \\
\text { same size but for different layers (albedo, } \\
\text { roughness, metallic, normal); Web interface to } \\
\text { test on a 3D model live. }\end{array}$ & $\begin{array}{l}\text { Multiple } \\
\text { solutions } \\
\text { problem }\end{array}$ & $\begin{array}{l}\text { Subjective } \\
\text { verificatio } \\
\mathrm{n}\end{array}$ & No & Maybe \\
\hline 7 & $\begin{array}{l}\text { Promote 3D work of } \\
\text { scientific illustrator } \\
\text { artists }\end{array}$ & $\begin{array}{l}\text { Personal } \\
\text { WordPress } \\
\text { blog with 3D } \\
\text { content }\end{array}$ & $\begin{array}{l}\text { Allow to upload, view, and interact with a 3D } \\
\text { model. Support main formats: FBX, OBJ, GLB, } \\
\text { 3DM, and PDB for biology. Walk inside virtual } \\
\text { spaces. Security of models. }\end{array}$ & $\begin{array}{l}\text { WebGL is } \\
\text { not } 100 \% \\
\text { secure. }\end{array}$ & Yes & Yes & Yes \\
\hline 8 & $\begin{array}{l}\text { Make an } \\
\text { environment for } \\
\text { real-productions } \\
\text { from home }\end{array}$ & $\begin{array}{l}\text { Distant real- } \\
\text { time } \\
\text { production }\end{array}$ & $\begin{array}{l}\text { Place two actors in the same context even while } \\
\text { they act remotely. Support of Skeleton } \\
\text { estimation through web RGB cameras [6]. } \\
\text { Apply animation to 3D models that act as } \\
\text { puppets of actors. }\end{array}$ & - & Yes & No & Yes \\
\hline 9 & $\begin{array}{l}\text { Allow children to } \\
\text { provide realistic } \\
\text { animations to } \\
\text { avatars in 3D spaces }\end{array}$ & $\begin{array}{l}\text { Animate 3D } \\
\text { models with } \\
\text { camera input }\end{array}$ & $\begin{array}{l}\text { A child can apply 3D animation to a 3D avatar } \\
\text { using only an RGB camera [6]. Security issues } \\
\text { of cameras should be dealt. Create cameras } \\
\text { that embed safety mechanisms on hardware. }\end{array}$ & $\begin{array}{l}\text { Camera } \\
\text { security } \\
\text { issues }\end{array}$ & Yes & No & No \\
\hline 10 & Allow music & Audio to & Generate immersive 3D spaces with & - & Yes & Yes & Yes \\
\hline
\end{tabular}




\begin{tabular}{|l|l|l|l|l|l|}
\hline composers to & texture to 3D & photorythmics and sound. Web interface. & & \\
visualize & visualization & Blogspot generation capability. Node editor for \\
photorythmics as & component & real-time changes. 3D editor for objects \\
textures of 3D & positioning. Uploading of new 3D models. & & \\
models & & Position primitive 3D models, e.g. cubes. & & \\
\hline
\end{tabular}

In the second step, a brainstorming based on the aforementioned scenarios was carried out to discuss and present ideas about the tools/solutions necessary to be developed/implemented to accomplish the TO-BE scenarios among stakeholders, namely an experienced artist, an experienced journalist, and the project technical manager. Requirements elicitation was an iterative activity, where brainstorming and interviews were used. A specific template form for the requirements definition process was defined that it is an extension of Table 3 with more project related details that are out of the scope of the paper to present them. Next, in requirements Analysis, user requirements were clarified, categorized and documented to generate the corresponding specifications. A crucial step is the "Approval of end-users". Therefore, we have conducted a survey in order to mine the opinion of the end-users namely artists, journalists, architects, and informatics scientists regarding the posed requirements.

\section{Survey results}

The main target of the electronic survey is to allow media content creators to evaluate and validate the proposed TO-BE scenarios and the requirements that were found during the Preparation and Elicitation phase. 47 individuals have participated in our survey which were reached from social media such as Facebook, Twitter, and LinkedIn and through the dissemination actions of our project [1]. The survey consists of 4 parts.

1. Part I analyzed in Section 4.1 consists of questions regarding the demographics of the participants.

2. Part II treated in Section 4.2 contains the previous experience of the participants (the AS-IS scenarios).

3. Part III coped in Section 4.3 contains the main results, namely the validation results of the proposed scenarios (TO-BE scenarios).

4. Part IV outlined in Section 4.4 is an overview of the comments that participants have provided.

In the following we present the acquired information. In Section 5 - Discussion, the results are analyzed in detail.

\subsection{Demographics}

\section{A. Nationality of participants}

The nationality distribution of the participants can be in Figure 2. The majority of the participants were located in Greece (75\%) whereas the rest of the participants were located in Belgium, Bulgaria, Germany, Hungary, Italy, Malta, Spain, Switzerland and the United Kingdom.

\section{B. Educational background of the participants}

As it is seen in Figure 3, the 18,39\% of the participants stem from Journalism and Mass Media Communication (MMC). Significant participation is from Fine Arts $(8,17 \%)$, Informatics (8,17\%), and Architecture (6,13\%). Other participants stem Advertising, Design, Education, Gaming, Humanities, Marketing and Social Sciences with 1.2\%. 


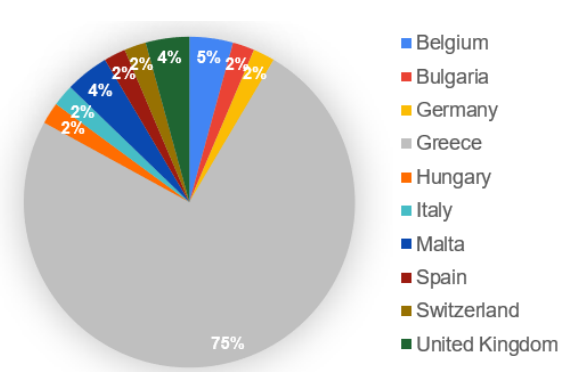

Figure 2: Nationality of the participants

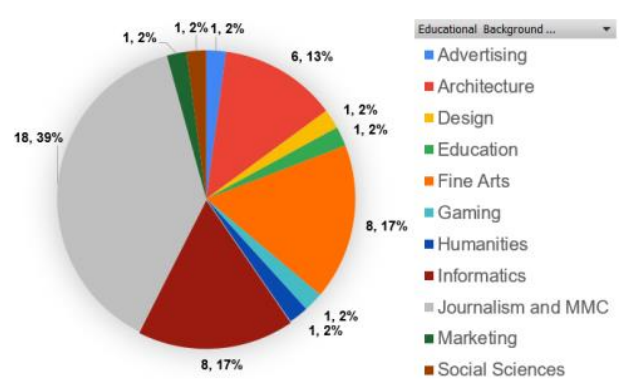

Figure 3: Educational Background.

\section{Age group of the participants}

The age group distribution of the participants can be seen in Figure 4 . The majority of the participants stems from the 18-25 yo group (49\%), followed $25-35$ yo group (28\%), 35-45 yo group (15\%), and the $45-55$ yo group $(8 \%)$.

\section{Type of employment organization}

As it is seen in Figure 5, most of the participants stem from Universities (55\%), Private Companies (24\%), and Research Centres (13\%). Other types of employment are Freelancers (4\%), Media Organizations (2\%) and NGOs (2\%). As regards individuals from Universities, their age distribution is seen in Figure 6. Mainly Bachelor and M.Sc. students have participated with a percentage of $80 \%$.

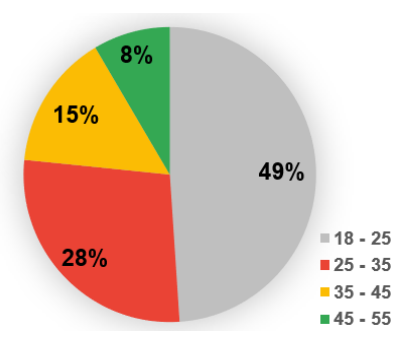

Figure 4: Age group of participants
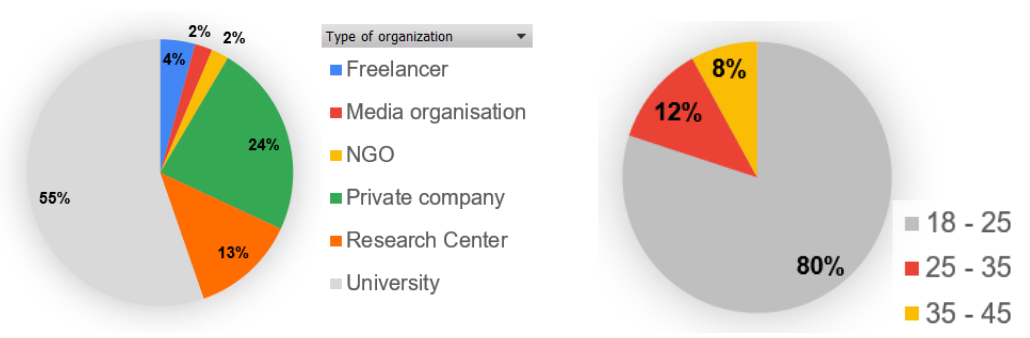

Figure 6: Age group from Universities 


\subsection{Previous experience collection and the AS-IS scenarios}

\section{A. Software use for creation}

In this question, participants have provided information about the experience with existing software for creation activities. Multiple selection of answers was possible from the list of tools that were described in Section 2. The results are shown in Figure 7.

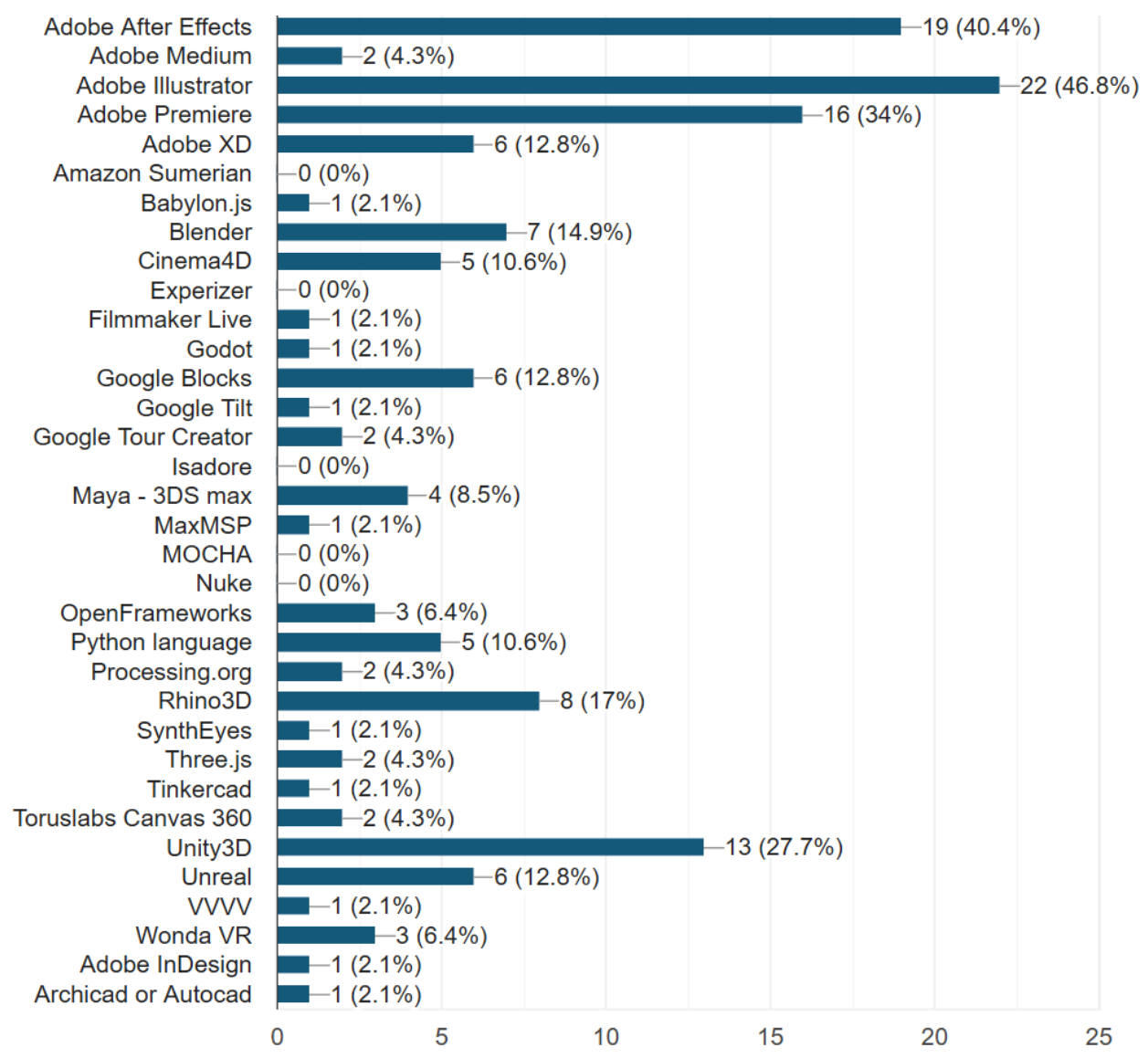

Figure 7: Most used software tools for creativity.

Most of the participants use Adobe Illustrator (46.8\%) for graphics design, Adobe After Effects $(40.4 \%)$ for applying effects on video and Adobe Premier for editing videos. Next, Unity3D graphics engine is used for 3D experience production (27.7\%). Rhino3D is popular with $17 \%$ and Blender is popular with $14.9 \%$ which are both 3D design programs. Adobe XD for mobile and web experience design, Google blocks for 3D design in VR, and Unreal graphics engine for 3D experience creation are also popular with $12.8 \%$. Cinema4D, Maya-3DSMax design tools and Python programming language show some indication for increased usage.

\section{B. Promotion and Monetization software}

Participants voted which software tools they use as regards promoting and monetizing their work. The distribution of the most voted tools are shown in Figure 8. It is seen that social media such as Instagram is prevalent with $78.7 \%$, Facebook follows with $72.3 \%$, next is Youtube with 55.3\%. LinkedIn is also popular with $42.6 \%$, Wordpress personal blog has received 27.7\%, whereas Tik-tok and Blogspot have received $25.5 \%$ each. Less used software are Twitch gaming social media and Wix web page creator with $10.6 \%$. CGtrader and Turbosquid repositories for selling 3D models have low percentages with $6.4 \%$. Mozilla Hubs and Playcanvas as 3D space creation tools for multiplying activities have received $4.3 \%$. 


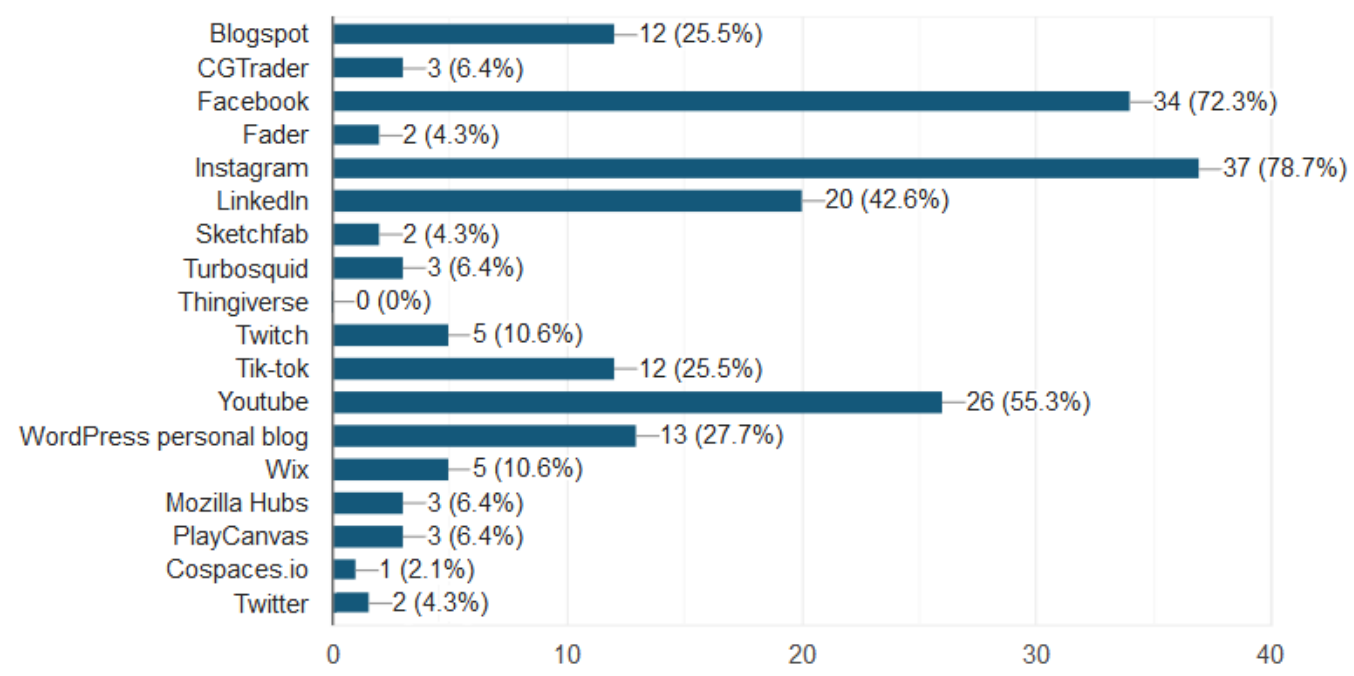

Figure 8: Most used tools for promotion and monetization.

\subsection{Evaluation of the TO-BE scenarios and requirements}

This is the main part of the survey. 6 TO-BE scenarios are selected from Table 2 which are relevant to our project [1]. Then, several statements per scenario are composed according to Table 3. Each statement can be rated in a 5 grade Likert scale where $\mathbf{1}$ corresponds to a disagreement and 5 stands for an agreement with the statement. The results for the evaluation of each of the 6 scenarios are presented Figure 9.1, Figure 9.2, Figure 9.3, Figure 9.4, Figure 9.5 and Figure 9.6, respectively. Scenario 1 was about the "Visualization of 3D models in web pages" and it consists of four statements for validation.

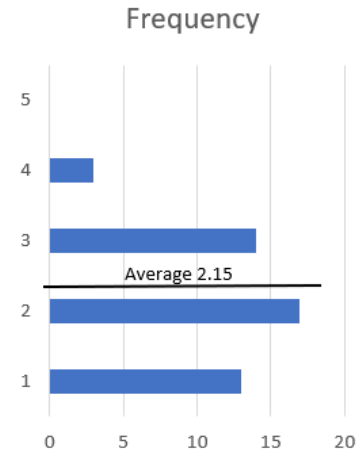

(a)

Q1.1. The current webpages are adequate, there is no need to visualize 3D models

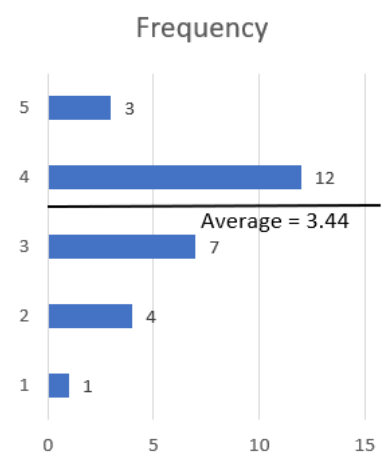

(b)

Q1.2. The existence of 3D models in web pages will cause a significant increase in downloading time and will demand high-end client devices

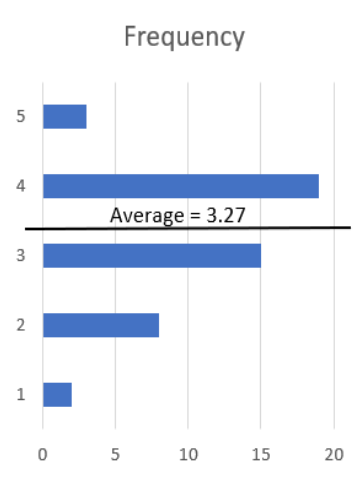

(c)

Q1.3. There is a need to insert 3D models in web pages as current software for web pages do not support the insertion of 3D models

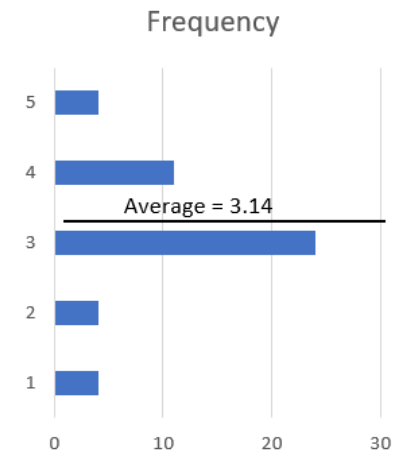

(d)

Q1.4. I can insert 3D models (e.g. through iframes) but it is not possible to visualize the media in the way I want (e.g. as an overlay over HTML elements)

Figure 9.1: Scenario 1 statements and validation results.

Scenario 2 is "Do 3D special effects in web or mobile?" and it consists of four statements for validation as shown in Figure 9.2. 


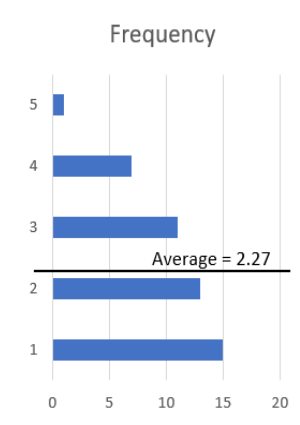

(a)

Q2.1. Desktop software is very good, web/mobile will never become better

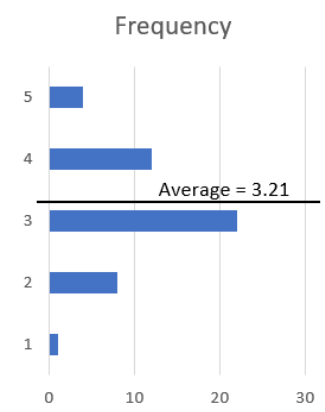

(b)

Q2.2. Suitable for amateur or semi-pro makers with average quality needs

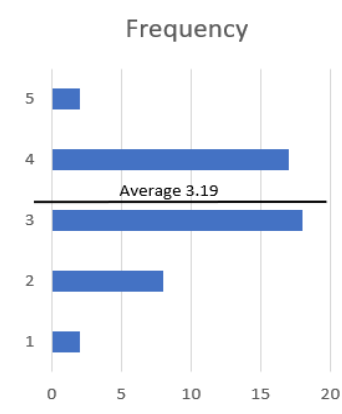

(c)

Q2.3 Suitable only through web technologies that are mature enough

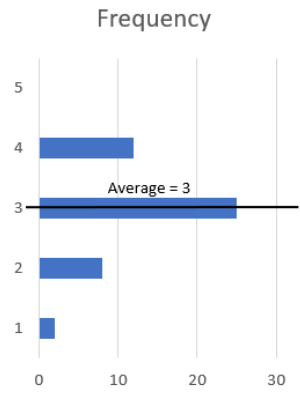

(d)

Q2.4. Suitable only through mobile technologies that are mature enough

Figure 9.2: Scenario 2 validation results.

Scenario 3 was about the "Inside a VR world make edits on a video stream, e.g. cuts or apply filters on videos?" and consists of three statements for validation as shown in Figure 9.3.

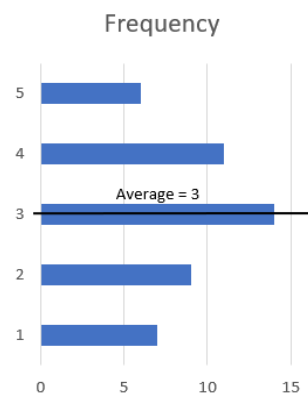

(a)

Q3.1. VR metaverses as editing environments are not suitable for 2D media editing.

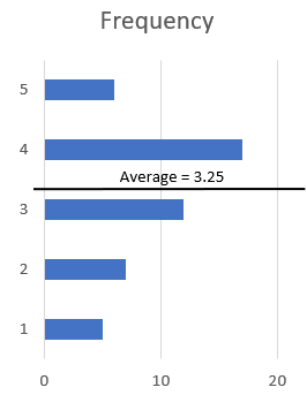

(b)

Q3.2. It is difficult to do video edits inside 3D environments.

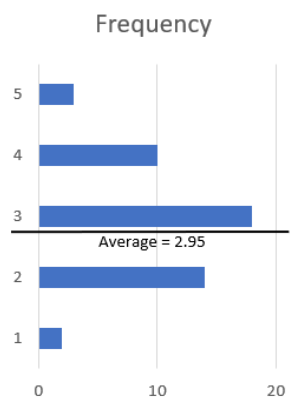

(c)

Q3.3. Only valuable if many people can edit the video simultaneously in a collaborative VR environment.

Figure 9.3: Scenario 3 validation results.

Scenario 4 was about the "Promote artistic media inside VR worlds?" and it consists of five statements for validation.

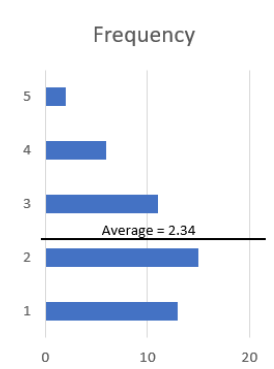

(a) Q4.1 - It will cause the media to be commercially saturated, i.e. exposed too much.

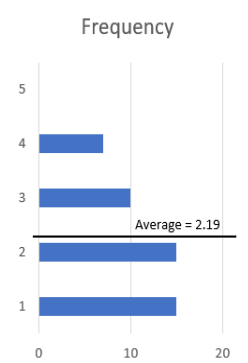

(b) Q4.2 - It is a bad idea because 3D models could be easily stolen.

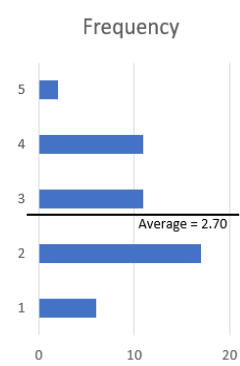

(c) Q4.3 -

Interesting as long as it is not for free for end-users to enter.

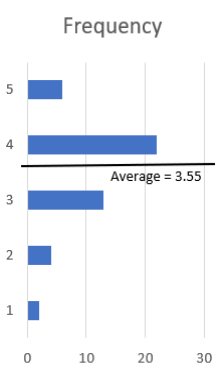

(d) Q4.4 - Interesting as long as it can be easily accessed through or expose the information to widely adopted social networks.

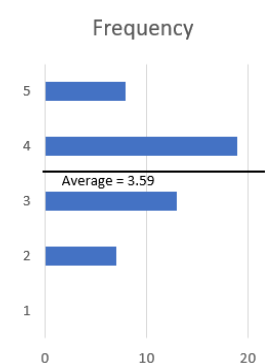

(e) Q4.5 Interesting because existing repositories are not visualizing or promoting my media enough.

Figure 9.4: Scenario 4 validation results. 


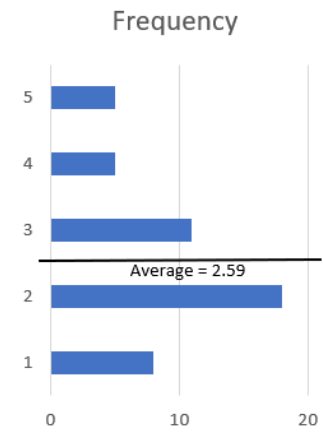

(a)

Q5.1 - It is a bad idea since next generation social VR environments are more attractive.

Scenario 5 was about the "Theme dedicated VR experiences for personal or joint blogs?" and it consists of four statements for validation as shown in Figure 9.5.

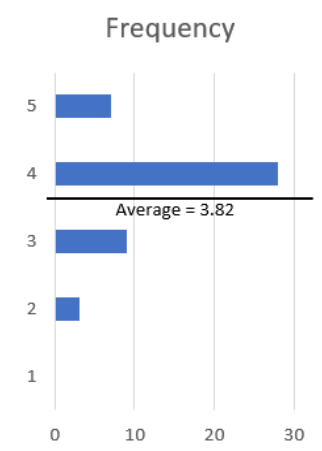

(b)

Q5.2 - Interesting because the features offered can be tailored better to personal interests.

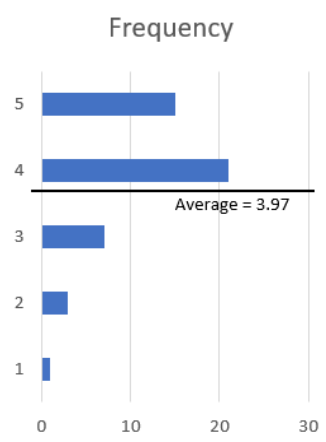

(c)

Q5.3 - Interesting because COVID19 has raised the attention of the public into realistic biological information potentially accessible through VR nanoworlds.

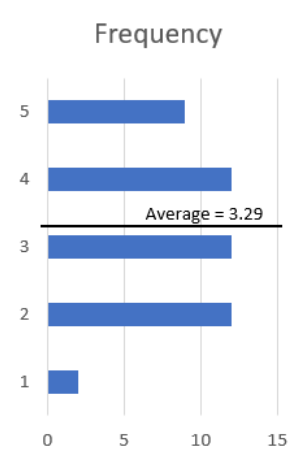

(d)

Q5.4 - It is a good idea as long as the developed VR experiences should not try to mimic reality, just be imaginary spaces such as illusionary spaces without perspective rules.

Figure 9.5: Scenario 5 validation results.

Scenario 6 "Make 3D models design inside VR spaces?" and it consists of four statements for validation as shown in Figure 9.6.

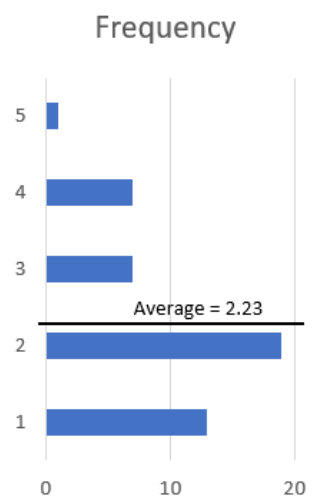

(a)

Q6.1 - It is a bad idea because it is easier to draw $3 \mathrm{D}$ models with $2 \mathrm{D}$ interfaces using keyboard/mouse and a professional software.

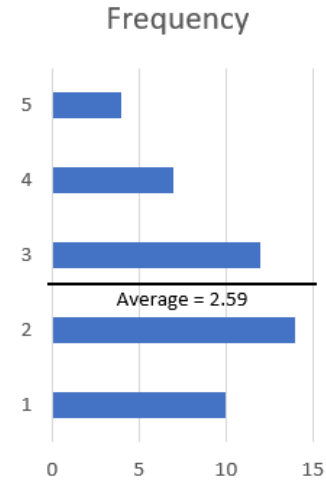

(b)

Q6.2 - Interesting for amateur artists (children, educators) but not for professional artists.

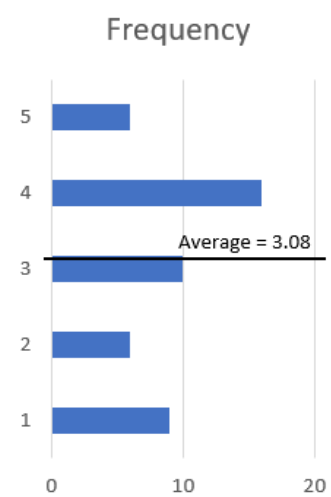

(c)

Q6.3 - Interesting but I am not willing soon to buy a 3D headset to use it.
Frequency

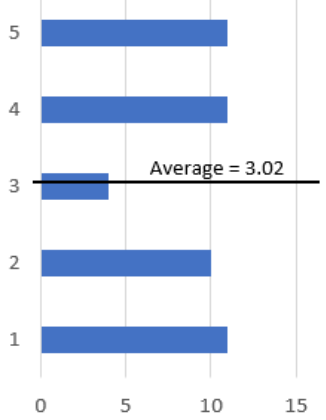

(d)

Q6.4 - I have never seen such an application.

Figure 9.6: Scenario 6 validation results.

\subsection{General comments}

The overall comments received by participants were divided into 4 categories, namely Interfaces, Barriers, Benefits, and Personalization. The comments regarding interfaces are:

1. Easy to use interfaces.

2. Easy ways of editing in a 3D environment.

3. Accessible, cloud - based co-design software with a solid source-control system for digital assets of all kinds would be nice.

4. VR can be multimedia converged experience, and users should have freedom to create and project their contents inside and outside the VR space. 
5. An online platform for VR content is interesting for idea exchange / moving the technology beyond the status quo. The same way that $3 \mathrm{D}$ models are available for sketch-up, perhaps there could be a repository for VR environments, for drag and drop solutions for scenes, educational subjects, etc.

6. VR environment to create 3D models.

7. VR/AR engineering \& training application including detailed human computer interaction via fingers haptic devices.

Comments 1 and 2 refer to the easiness of the interfaces and particular in the editing capability inside the 3D environment. Comment 3 refers to the accessibility of the solution mostly achieved through cloud and to the coverage of all types of media. Comment 4 refers to media convergence, i.e. to allow the combination of several types of media in order to create a new solid type of media. Freedom to create, project personal content, and expose media outside VR environments should be also possible. Comment 5 is towards an online platform for VR content, namely to make a repository for whole scenes as prebuild solutions for certain scenarios. Commend 6 is towards the idea to create 3D models inside the VR environment. Comment 7 suggests that VR applications for training are also interesting if they also exploit peripheral devices such as haptic devices.

The comments regarding Barriers are as follows:

1. I'll stick to $2 \mathrm{~d}, 3 \mathrm{D}$ is overpriced.

2. Basic training material.

3. Online VR/AR applications that utilize 5G to render 3D models at real time.

4. I believe that collaboration tools would be great to have but sharing spaces to create 3D seems one or two steps too far or too fast.

5. A better user experience while drawing/designing and a sandbox toolset for publishing my work in a device-independent environment.

6. The key is seamless interfaces where creators do not wow at the tool itself, but rather it becomes transparent and they can just focus on their creative processes.

Comment 1 refers to the high price of 3D models with respect to the 2D media. As regards Comment 2 it highlights the need of training material for using the authoring tools. Comment 3 regards the internet speed that allows to download 3D models on VR/AR applications on the fly improving thus the user experience. Comment 4 refers to the collaboration of many users for VR environments or 3D models creation but the sharing of spaces towards collaboration with other users is a far fetched goal. Comment 5 focuses on the device-independent environment for publishing the results, whereas Comment 6 is highlighting the need for reducing cognitive burden so that the user can focus on the creative process.

As regards the category Benefits, the comments received are as follows:

1. Access \& mutual professional benefits.

2. Variety of subjects and costs; interactions between the designers.

3. New mediums, that will expand my creativity.

It is inferred from Comment 1 that creators should have some benefits after creating the content. Comment 2 refers to the variety of media so as the space can be commercially exploitable, as well as to the interaction across the designers in order to improve the final result. Comment 3 refers to the combination of media that will allow to enhance creativity.

As regards Personalization category, two comments were received, namely:

1. VR personal spaces rather than ad hoc $2 \mathrm{D}$ web pages

2. VR experience can be both realistic and illusionary and visualisation styles should not limit the way users experience the virtual reality space 
Comment 1 refers to the use of VR spaces as a replacement of the traditional 2D web pages. Comment 2 is addressing the fact that VR experiences can be expanded to illusionary spaces rather than limited to the representation of real spaces.

\section{Discussion}

\subsection{Demographics}

Demographics provide more insights about the survey results. As regards the nationality of the participants, it is seen that all participants are Europeans. Most participants are from Greece with a 75\% which makes the research mostly focused on the Greek media status quo. As regards the educational background of the participants, it is seen that Journalism and Mass Media Communication, Fine Arts, Informatics and Architecture dominate. These disciplines have a flexibility as regards the use of tools both for 2D and 3D design. As regards the age group of the participants, it is observed a high participation of youth (18-25yo) which is about $50 \%$, and gradual decrease at half when observing older groups until 45-55yo group that participated with $8 \%$ (Figure 4). A remark is that no participants were above 55yo. This can be interpreted as youth is more keen on using electronic tools for artistic content creation. As regards the organization that participants stem, it is seen that most of the participants were from academia. Private companies have also a strong presence with $24 \%$. From Figure 6, it is observed that participants from universities are mostly students with a percentage of $80 \%$.

\subsection{AS-IS scenarios and previous experience}

The software tools popularity not only shows the popularity of tools but also the popularity of each type of content. 2D content creation tools of Adobe such as Illustrator, After Effects, Premier, and XD are very popular. This can be explained by the fact that most of the participants stem from media and fine arts. Unity3D and Unreal graphics engines show increased popularity also which indicates that game creation and storytelling is popular. However, they have lower rates than 2D creation tools which can be explained by the fact that they need programming skills and require more training to produce the final result. Rhino, Blender, Maya-3DS Max, and Cinema4D are also popular as tools for 3D designing content. The increased rates for Rhino can be explained by the participation of Architects in the research which is a tailored solution for them. Google Blocks is a surprise as it was not expected to receive more votes than Adobe Medium and Google Tilt. Thedr are all 3D design tools that are used through VR glasses but Google Block is only for low polygon models whereas the other two can achieve more realistic models. It seems that low polygon design is more attractive to be done inside VR environments. Python language is also popular but it seems to be affected by the participation of the informatics experts.

The results of the question regarding promotion and monetization software tools and platforms indicate that major social media platforms such as Instagram, Facebook, Youtube, and LinkedIn are widely adopted by media creators to promote and monetize their work. "Facebook Creator Studio" and "Youtube Studio" allow monetization through advertisement. LinkedIn is for promoting career opportunities and portofolio. Instagram is a smartphone centred application without desktop front-end. The latest addons of Instagram such as the Live Shopping allows to monetize from non-electronic art such as hand made paintings. Another pathway of promotion and monetization is through personal websites achieved by WordPress, Blogspot, and Wix. All these three platforms provide a simple way to make personal websites through templates without requiring programming. 


\subsection{TO-BE scenarios evaluation}

Scenario 1 refers to the visualization of 3D models in web pages. The participants disagreed with Q1.1 "Current web pages are adequate, there is no need to visualize 3D models" as indicated by the average score, namely 2.15 . This reveals that participants consider the presence of 3D models in web pages as a great need. However, according to the average score Q1.2, namely 3.44, they believe that the 3D models will significantly increase downloading time and will require high-end client devices. The need of 3D models in web pages is the result that the current web pages design software does not support the insertion of 3D models (Q1.3, average score: 3.27). Q1.4 regarding if they know such software, it is balanced to undecided opinion (Q.14: 3.14).

As regards Scenario 2 about the question "Do 3D special effects in web or mobile", the results are as follows. Q2.1 regarding the belief that mobile and web software will never have the potential of desktop devices, most participants disagreed with a score of 2.27. As regards Q2.3 that such technologies are suitable for amateurs or semi-pros with average quality needs, the opinion is not converging to a direction (Q2.3). However, as regards the choice of web or mobile technologies, most participants answered towards web technologies with a score of 3.19 vs 3 for mobiles. Analyzing further the results 17 participants have voted for web technologies against 12 for mobile technologies.

As regards Scenario 3 about making edits on video streams inside VR worlds, the survey has revealed the following. As regards Q3.1 that "VR metaverses as editing environments are not suitable for 2D media editing", the opinion of the participants is undecided with an average score of 3 and no tendency towards a direction. In general they agreed that it is difficult to do video edits inside a 3D environment with an average score of 3.25. About Q3.3 that regards the participation of many users inside a 3D environment will make VR editing valuable, the opinion is slightly bending towards the negative direction with a score of 2.95. From all the scenarios, this scenario has received the most undecided scores.

As regards Scenario 4 about "Promoting artistic media inside VR worlds", the statement Q4.1 about the commercial saturation of the media due to high exposure has received strong disagreement with a score of 2.34. Almost the same was the response for Q4.2 about the risk of the 3D models to be stolen if exposed in VR environments with a score of 2.19 indicating that participants consider VR space as a safe space for 3D content. As regards Q4.3 about the introduction of a fee to enter VR spaces, the users show a slight disagreement with a score of 2.70. As regards the exposure to and accessibility from social media (Q4.4), the participants have shown great agreement with a score of 3.55, indicating that collaboration with social media is an important factor for such a scenario. Even stronger was the opinion that the existing repositories do not promote and visualize content adequately with a score of 3.59.

As regards Scenario 5 about the "Theme dedicated VR experiences for personal or joint blogs", the participants disagreed with the statement "Q5.1 - It is a bad idea since next generation social VR environments are more attractive" with an average score of 2.59. This indicates that there is an innovation potential of such a scenario. In general they found the idea interesting because the features offered can be tailored better to personal interests (Q5.2, average score 3.82). Also, they found the idea of COVID19 nano-worlds interesting with the highest score observed among all questions, i.e. 3.97 (Q5.3). The idea of illusionary spaces however did not raise significant interest with a score of 3.29 (Q5.4).

As regards Scenario 6 about the design of 3D design models inside VR spaces, the participants disagreed with the statement "The idea is bad because traditional software allows easier to design with mouse and keyboard" (Q6.1) with a score of 2.23. They also disagreed that such a design method will be for amateur artists with a score of 2.59 (Q6.2). Obviously, the idea of designing 3D models inside VR spaces is good for professional 
creators, however, as it is inferred also from the comments, the interfaces are not very intuitive. There are also some issues regarding hardware as 21 of the participants are not willing to buy a VR headset soon (Q6.3, average score 3.08). There is also a great amount of participants that have not seen similar applications yet as 22 participants stated so (Q6.4).

\subsection{Individual comments}

Most individual comments regarded the interfaces of VR environments. The comments related to Interfaces refer to easiness, accessibility, and haptic devices interconnection. It is true that current VR systems require a process to download, install, and to learn the interfaces of the design tool. As regards accessibility, still many devices do not allow the use of VR headsets with prescription glasses. Another issue is the cost as they are still expensive for amateur creators with a cost around 400 euros. All these seem to be the most important barriers for content creators. Another evident issue is the cloud availability and the co-design capabilities. Many creators would like a cloud oriented application where assets, scenes and projects can be easily created, shared, and co-edited in joint repositories. For the time being, most design applications limit the design capabilities on local use or on single user cloud repositories. For example, Google Blocks and Google Tilt have Google Poly repository which however is going to close in June 2021. The low penetration of VR design tools due to the high cost of devices might be a reason that such repositories did not find acceptance by users.

As regards the comments relevant to Barriers, it seems that users have many concerns as regards 3D content creation. Most of the Barriers refer to the design inside VR environments and only one refers to the expensiveness of 3D content as for the time being too expensive in order to be used as an artistic improvement for various applications. As regards VR environments, it seems that they are missing enough training material. There are limited resources as regards viewing other designers designing in VR as the approach to create 3D models in VR space escapes from the traditional way of designing 3D models. Shared spaces for multiple users to design seems to be a far fetched target for the time being as many things are not solved for a single user. A comment also refers to the $5 \mathrm{G}$ connectivity that will enhance downloading times.

As regards the category Benefits, two comments refer to monetization, namely the mutual professional benefits and the existence of a variety of subjects and costs. This might be interpreted as an increased need for a monetization plan that allows mutual benefits to collaborators in VR space. Another comment is new mediums which might be interpreted as a new media that can actually merge all types of media.

\section{Conclusions and future work}

The demographics of the survey suggest that the tools to be developed should be tailored well to youth, e.g. by a low price plan, as well as to companies with a high budget plan. As regards the creation tools and the type of software, in general, we can infer that Adobe desktop tools for 2D content creation are widely used. Tools for 3D content creation are not limited to certain brands, apart from the Unity3D graphics engine. Promotion and monetization is correlated to the exposure of content in Instagram, Facebook, Youtube and LinkedIn. It should be investigated why Instagram is more popular than other social media platforms. Also content creators tend to have their own web site in WordPress, Blogspot and Wix as these three platforms provide a simple way to make a personal website through templates. Therefore, proposed solutions should be also tailored to such platforms. 
Scenario 1, namely the exposure of 3D models in web sites is ranked highly according to the responses of the users. Content creators would like to expose their 3D models in web pages as long as the downloading time and the end-user device requirements is kept low. It is also inferred that creators do not have or do not know a certain methodology to expose 3D content. If this is combined with the conclusions of the previous paragraph, it seems that the content creators do not know how to embed 3D models in WordPress, Blogspot, and Wix. Exposing 3D content (or images of it) in Instagram, Facebook, Youtube and LinkedIn is very important for dissemination purposes. Scenario 2 about achiening visual effects in web or mobile is bending towards web applications for both amateur and professional users. This might be interpreted that the latest technologies such as 5G internet, WebAssembly, the upcoming WebGPU have increased the trust of creators on web browsers. The conclusions from Scenario 3 are rather mild. Users are not balancing towards a direction indicating only that the editing of videos inside VR space is difficult or not interesting to them. Scenario 4 about the promotion of artistic media inside VR worlds has also raised the interest of participants. It is inferred that creators believe that their content is not promoted well from current repositories. The accessibility of VR spaces from social media and the exposure of content to social media is also important. As regards Scenario 5, the idea of a personal or joint blog in a VR space has seemed to be attractive as a mean to express better personal interests. The idea of a nano VR space with information regarding biology and most specifically to COVID19 mechanisms seems to be more attractive than illusionary spaces of other types. Towards this direction, one of the most unexploited resources in Art, but prominent in Biology, is the Protein Data Bank (PDB) [7]. It provides rich data for visualization such as the protein related SARSCOVID19 as shown in Figure 10.

Figure 10. Structure of SARS-CoV-2 $S$ protein in complex with Receptor Binding Domain antibody [7].

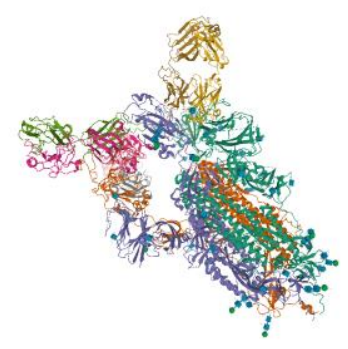

Scenario 6, which addresses the case of designing 3D models in VR space has been also attractive. However, it is prompted that the interfaces should be improved, the headsets should be more accessible, the software should be better promoted, and sufficient training material should be available.

The IEEE 830 requirements specification methodology has two additional steps, namely Requirements Specification, where the requirements are brought into a suitable and unambiguous form, and Requirement Validation, namely the review and the validatation of the requirements for clarity, consistency and completeness. These are future steps that will be executed internally in the project with the ultimate goal to end up with a commonly agreed collection of raw requirements. Also, the methodology has a mechanism for defining more low granularity requirements, namely a role playing theatre also refered as a game (see at the bottom of Figure 1). This role play theatre is used to simulate how a project's stakeholders would interact between them, and with the hypothetical prototype of the project. This theatre is divided into three steps: the Preparation; the Execution and the Review steps. The preparation step deals as the name indicates with the preparation and implementation of the theatrical plays (games) to be used in the next step. The gaming step comprises the workshop, where the gaming sessions happen. The review step consists of the analysis and documentation of the requirements in each repetition. This game will be executed multiple times to find "hidden" requirements and to improve the results.

Funding: The research leading to these results has received funding from the European Union H2020 Horizon Programme (2014-2020) under grant agreement 957252, project MEDIAVERSE (A universe of media assets and co-creation opportunities at your fingertips). 


\section{Acknowledgments: -.}

Conflicts of Interest: The authors declare no conflict of interest.

\section{References}

1. MediaVerse Project, Horizon Programme H2020 EU, 2020-2023, “A universe of media at your fingertips," GA no 957252, https://MediaVerse-project.eu

2. IEEE Standard 830-1998, Recommended Practice for Software Requirements Specifications. New York: IEEE Press.

3. MSEE Project Consortium, Deliverable 51.1, “Applicability of existing user requirements approaches in MSEE. MSEE Manufacturing Services Ecosystem." 2011.

4. Marcelino-Jesus, E., Sarraipa, J., Agostinho, C., Ricardo Jardim-Goncalves. "A Requirements Engineering Methodology for Technological Innovations Assessment." In ISPE International Conference on Concurrent Engineering, pp. 577-586. 2014.

5. Fuchs, Norbert E.; Schwertel, Uta; Schwitter, Rolf. "Attempto Controlled English - not just another logic specification language," International Workshop on Logic Programming Synthesis and Transformation. Lecture Notes in Computer Science. 1559. Springer. pp. 1-20. doi:10.1007/3-540-48958-4_1. ISBN 978-3-540-65765-1, 1998.

6. Cao, Z., Hidalgo, G., Simon, T., Wei, S.E. and Sheikh, Y. OpenPose: realtime multi-person 2D pose estimation using Part Affinity Fields. IEEE transactions on pattern analysis and machine intelligence, 43(1), pp.172-186, 2019.

7. Berman, H. M., Westbrook, J., Feng, Z., Gilliland, G., Bhat, T. N., Weissig, H., Shindyalov, I. N., Bourne, P. E., “The Protein Data Bank," Nucleic Acids Research, Volume 28, Issue 1, 1 January 2000, Pages 235-242, https://doi.org/10.1093/nar/28.1.235 